Research Note

\title{
Intake of Water Containing Condensed Tannin by Cattle and Sheep
}

\author{
Scott L. Kronberg \\ Author is Animal Scientist, US Department of Agriculture-Agricultural Research Service, Northern Great Plains Research Laboratory, \\ Mandan, ND 58554, USA.
}

\begin{abstract}
Ingestion of small amounts of condensed tannin (CT) by ruminants can prevent bloat, improve nitrogen retention, and reduce excretion of urea, a precursor of ammonia and the greenhouse gas nitrous oxide. Because grasses and many forbs don't contain $\mathrm{CT}$, it is desirable to find a reliable way to have ruminant livestock ingest small amounts of CT when they consume high-quality forage. Putting CT in their drinking water may be a reliable approach, but only if all animals drink enough to meet their requirements for water. Therefore, objectives of this study were to determine the amount of variation in intake of water containing different amounts of CT when this was the only water available, and if cattle and sheep would drink water with CT in it if offered tap water simultaneously. Animals were penned or pastured individually, fed twice daily (first cattle and sheep trial) or grazed (second cattle trial) and had ad libitum access to tannin water, tap water, or both. Liquid intake was measured daily. Steers drank tannin solutions (mean daily intake 49.7-58.3 kg), but variation in intake among steers was higher than for tap water (SD were $44 \%-58 \%$ greater for the two most concentrated tannin solutions). At the highest concentration of tannin, steers ingested $2.3 \%$ of their daily feed intake in CT. During most of the preference trial, steers preferred water over tannin water when offered both simultaneously $(P \leq 0.002)$, but drank some tannin water each day. Sheep drank tannin solutions, but individual variation in tannin solution intakes were greater than for tap water. Placing CT in water of cattle and sheep may be a useful way to put small amounts of CT in them. However, they will likely drink less tannin water if normal water is available.
\end{abstract}

\section{Resumen}

La ingestión de pequeñas cantidades de taninos condensados (TC) por rumiantes puede prevenir el timpanismo, mejorar la retención de nitrógeno y reducir la excreción de urea, precursor del amoniaco y del gas de invernadero, oxido nitroso. Como muchas hierbas y pastos no contienen TC, es conveniente encontrar una forma de hacer que el rumiante ingiera pequeñas cantidades de TC cuando consuma forrajes de alta calidad. Una forma confiable podría ser agregar los TC en el agua consumida, siempre y cuando todos los animales beban lo suficiente para llenar sus requerimientos de agua. Por lo tanto, los objetivos de este estudio fueron determinar la variación en el consumo de agua con diferentes cantidades de TC siendo la única agua disponible. Asimismo, se evaluó si el ganado y los ovinos beberían el agua con TC si esta era ofrecida simultáneamente con agua normal. Los animales fueron encorralados o pastoreados individualmente; alimentados dos veces al día (primer ensayo del ganado y ovinos), o en pastoreo (segundo ensayo del ganado) con libre acceso al agua con taninos y/o al agua normal. El consumo de agua fue medido diariamente. Los novillos bebieron las soluciones con taninos (consumo medio diario de 49.7$58.3 \mathrm{~kg}$ ) pero tuvieron una mayor variación en el consumo entre animales que con el agua normal (la desviación estándar fue 44\%-58\% superior para las dos soluciones con mayor concentración de taninos). En la concentración más alta de taninos, los novillos ingirieron $2.3 \%$ de su consumo diario de alimento en TC. Durante la mayoría de los ensayos, los novillos prefirieron el agua normal sobre el agua con taninos cuando estas fueron ofrecidas simultáneamente $(P \leq 0.002)$, no obstante, bebieron algo de agua con taninos diariamente. Las ovejas bebieron las soluciones con taninos, pero las variaciones individuales en el consumo de soluciones con taninos fueron mayores que en el agua normal. El agregarle TC al agua del ganado y ovejas puede ser una buena forma de proporcionarles pequeñas cantidades de TC, sin embargo los animales probablemente beberán menos agua con taninos si tienen acceso al agua normal.

Key Words: livestock, pollution reduction, quebracho tannin

\section{INTRODUCTION}

Ingestion of small amounts of condensed tannins (CT) by ruminants can improve their nitrogen-use efficiency and increase net apparent absorption of essential amino acids (Min et al. 2003). Growing levels of nitrogenous compounds (e.g., ammonia, nitrates, nitrous oxide) in the environment are

Correspondence: Scott Kronberg, USDA-ARS, Northern Great Plains Research Laboratory, PO Box 459, Mandan, ND 58554, USA. Email: scott.kronberg@ars.usda.gov

Manuscript received 10 March 2007; manuscript accepted 7 December 2007. associated with human health and environmental concerns (Vitousek et al. 1997; Wolfe and Patz 2002). Nitrogenous compounds (especially urea) in ruminant excretions are important precursors of these compounds (Sherlock and Goh 1984; Thomas et al. 1988), and ingestion of CT by ruminants can reduce urine urea concentration and overall nitrogen excretion. Ingestion of CT can reduce methane emissions by ruminants (Woodward et al. 2002), and bloat in cattle (Min et al. 2003).

The optimal daily intake of CT when ingested as a constituent of forage appears to be $2 \%$ to $4 \%$ of dry matter 
intake with less having little or no benefit and more having a toxic effect, but this level depends on the type of CT ingested (Waghorn and Shelton 1995; Min et al. 2003). For grazing cattle and sheep, the benefits described above are limited by lack of CT in most grasses and some broadleaf species (e.g., alfalfa, Medicago sativa L.), and difficulty, in semiarid areas, in establishing and (or) maintaining single- or mixed-species pastures with forages that contain CT (Jefferson et al. 1994). For penned livestock, obtaining adequate intake of CT is possible by mixing it with their feed, but obtaining appropriate and uniform intake of a supplement containing CT may be difficult when they are grazing (Bowman and Sowell 1997). Therefore, supplying CT via their drinking water merits evaluation.

There can be considerable variation in intake of CT and other phytochemicals among individual ruminants (Pfister et al. 1997; Villalba et al. 2002). CT are soluble in water, but have an astringent nature in the mouth, so it's possible that some animals may not readily drink water containing CT. Because ingestion of adequate amounts of water is essential for the health and productivity of ruminants, it's essential that adding CT to water not cause some animals to drink inadequate amounts of water. Therefore, objectives of this study were to 1) determine if some cattle and sheep would drink much less water when small amounts of CT were put in it and 2) determine how much of a CT water solution cattle and sheep would drink when tap water was readily available.

\section{METHODS}

\section{Cattle Trial 1}

Ten yearling Hereford steers $(367 \pm 5 \mathrm{~kg})$ were individually penned outdoors for the trial. Pens were $3.8 \mathrm{~m}^{2}$ in size on level ground with no shade or windbreaks. Steers were fed cubes of chopped alfalfa-pea hay ( $15 \%$ crude protein as fed) at $3 \%$ of body weight $(\mathrm{BW}) \cdot \mathrm{d}^{-1}$ (half in morning and half in afternoon). They were allowed to adapt to the cubes, pens, and watering bowls (but had no adaptation to tannin water) for $14 \mathrm{~d}$, and at the end of this period all steers promptly ate all cubes and appeared to drink readily from the bowls. A liquid form of quebracho tannin (Tannin Corporation, Peabody, MA) was the crude CT extract used for this trial and the sheep trial. Quebracho tannin is derived from the quebracho tree (Schinopsis balansae Engl.) in Argentina, and was not an ideal material for this trial because it also contains soluble phenolics (Robbins et al. 1991). However, it was selected because it has been used in other studies with ruminants (Dawson et al. 1999; Villalba et al. 2002), and because large quantities are available. The sequence of tannin solutions offered to these steers was intended to give them $0.125 \%, 0.25 \%, 0.5 \%, 1.0 \%, 1.5 \%$, and $2.0 \%$ of their daily feed intake in CT. We assumed that they would drink similar amounts of these tannin-water solutions as they drank of tap water in a previous 4 -d period. Each concentration of tannin was offered for 4 to $6 \mathrm{~d}$, which was defined as a period. They were offered sequentially from lowest to highest concentration, and after the highest concentration of tannin was offered they were given tap water for $5 \mathrm{~d}$. Each steer obtained his water from a self-activated watering bowl that was checked daily and cleaned if necessary. If the bowl's water was contaminated with feces, the data for that animal for that day was not used. Liquid intake was measured with analog water meters on lines to each bowl. Average daily temperature and relative humidity were measured near the pens and averaged for each period of the trial. The MIXED procedure of SAS (1996) with repeated measures of daily fluid intakes was used to determine if the amount of CT in tap water influenced liquid intake. Unstructured, autoregressive, and compound symmetry covariance structures were evaluated and the autoregressive structure was used (smallest Akaike's Information Criterion [AIC] value).

\section{Cattle Trial 2}

For the second cattle trial, five yearling Angus crossbred steers $(470 \pm 34 \mathrm{~kg})$ were pastured individually but adjacent to each other on 0.4 ha of alfalfa (pre- to full-bloom growth stages) per animal. They consumed alfalfa (as hay and pasture) for $14 \mathrm{~d}$ before the trial began. In each pasture, two identical water tanks that each held $378 \mathrm{~L}$ were located with a space of $30 \mathrm{~cm}$ between them. One tank held water and the other held tannin water and the position of the two solutions was reversed at the midpoint of the 12-d trial. Daily intake of each type of water was measured at the same time each day using analog water meters. No rain occurred during the trial and the small amount of water lost to evaporation was assumed to be similar for both types of water. To make the tannin water, quebracho tannin in dry form (Tannin Corporation) was mixed with water at a ratio of $2.64 \mathrm{mg}$ of tannin powder per $1 \mathrm{~kg}$ of water, which was a similar concentration as the $1.0 \%$ solution in the first trial. The MIXED procedure of SAS (1996) with repeated measures of daily fluid intakes was used to determine if water type, day, and their interaction influenced liquid intakes. Unstructured, compound symmetry, and heterogeneous compound symmetry covariance structures were evaluated and compound symmetry was used (smallest AIC value).

\section{Sheep Trial}

The four sheep used in the trial were black-faced crossbred wether lambs $(57 \pm 5 \mathrm{~kg})$. Lambs were housed indoors in individual pens $\left(1.7 \mathrm{~m}^{2}\right)$ in a well-ventilated room with day and night temperatures set at $12.8^{\circ} \mathrm{C}$ and $4.4^{\circ} \mathrm{C}$, respectively. They were fed alfalfa pellets ( $16 \%$ crude protein as fed) at $3.5 \%$ of $\mathrm{BW} \cdot \mathrm{d}^{-1}$ (half of ration in morning and half in afternoon). Lambs were allowed to adapt to their pens and alfalfa pellets for a 14-d pretrial period. During the trial, feed intake was monitored for each feeding, and all pellets offered were rapidly consumed. The sequence of tannin solutions offered to these sheep was intended to give them $0.25 \%, 0.5 \%, 1.0 \%$, and $2.0 \%$ of their daily feed intake in CT. Each concentration of tannin was offered in a 20-L bucket for $1 \mathrm{wk}$, and they were offered sequentially from the lowest to highest concentration. Daily water intake was measured by determining the amount $(\mathrm{kg})$ of water removed from each bucket at the same time each day. Immediately after this first phase of the trial, sheep were simultaneously offered tap water and the $1 \%$ solution of tannin water (each ad libitum) for $9 \mathrm{~d}$ to determine if they would drink the tannin water when tap water was available. This tannin concentration was used for this test because their average intake of it was high in the earlier part of the trial. Pen location 
Table 1. Means, standard deviation, and minimum and maximum values for tap water and quebracho water ingested during eight phases of a trial with yearling cattle $(n=10)$ or five phases of a trial with lambs $(n=4)$ and average daily temperature and relative humidity during each phase of the cattle trial (lamb trial was in a controlled environment).

\begin{tabular}{|c|c|c|c|c|c|c|c|c|c|}
\hline \multirow[b]{2}{*}{ Species } & \multirow{2}{*}{$\begin{array}{c}\text { Type of } \\
\text { liquid }\end{array}$} & \multicolumn{3}{|c|}{ Liquid ingested $\left(\mathrm{kg} \cdot \mathrm{d}^{-1}\right)^{1}$} & \multicolumn{3}{|c|}{$\begin{array}{l}\text { Quebracho tannin ingested } \\
\text { (\% daily feed intake) }\end{array}$} & \multirow{2}{*}{$\begin{array}{c}\text { Average daily } \\
\text { temperature } \\
\left({ }^{\circ} \mathrm{C}\right)\end{array}$} & \multirow{2}{*}{$\begin{array}{l}\text { Average daily } \\
\text { relative humidity } \\
(\%)\end{array}$} \\
\hline & & Mean (SD) & Minimum & Maximum & Mean (SD) & Minimum & Maximum & & \\
\hline \multirow[t]{8}{*}{ Cattle } & Water & 46.84 a $(2.4)$ & 43.15 & 51.57 & - & - & - & 23.7 & 69.1 \\
\hline & T $0.125^{2}$ & 50.71 b (3.6) & 46.71 & 58.29 & $0.14(0.01)$ & 0.13 & 0.16 & 28.4 & 45.4 \\
\hline & Т 0.25 & 49.71 a (4.1) & 46.84 & 59.61 & $0.27(0.02)$ & 0.25 & 0.32 & 24.2 & 44 \\
\hline & Т 0.5 & 53.91 b (5.2) & 45.23 & 63.21 & $0.58(0.05)$ & 0.49 & 0.67 & 24.4 & 43.2 \\
\hline & T 1.0 & 56.44 b (3.9) & 47.01 & 60.56 & $1.22(0.09)$ & 1 & 1.3 & 17.9 & 53.4 \\
\hline & T 1.5 & 58.31 b (5.7) & 49.36 & 65.56 & $1.87(0.18)$ & 1.58 & 2.08 & 23.9 & 45 \\
\hline & Т 2.0 & 53.65 b (5.2) & 44.54 & 58.86 & $2.31(0.24)$ & 1.91 & 2.57 & 13.8 & 63 \\
\hline & Water & 46.31 a $(3.6)$ & 41.56 & 54.2 & - & - & - & 11.1 & 66.8 \\
\hline \multirow[t]{5}{*}{ Sheep } & Water & $8.261(0.585)$ & 7.712 & 9.084 & - & - & - & - & - \\
\hline & T $0.25^{3}$ & $6.55(0.658)$ & 5.584 & 7.034 & $0.22(0.04)$ & 0.19 & 0.27 & - & - \\
\hline & Т 0.5 & 7.517 (1.92) & 5.781 & 9.428 & $0.49(0.11)$ & 0.36 & 0.6 & - & - \\
\hline & T 1.0 & $8.449(2.38)$ & 6.371 & 10.72 & $1.11(0.27)$ & 0.77 & 1.38 & - & - \\
\hline & Т 2.0 & $7.825(0.784)$ & 7.063 & 8.764 & $2.08(0.36)$ & 1.71 & 2.56 & - & - \\
\hline
\end{tabular}

${ }^{1}$ Mean comparisons for liquid intakes of cattle are indicated by lowercase letters; means with different letters differ $(P \leq 0.05)$.

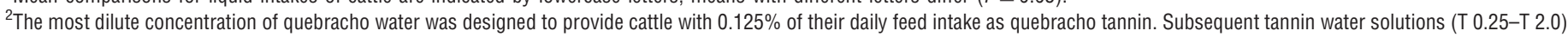
were designed to provide $0.25 \%, 0.5 \%, 1.0 \%, 1.5 \%$, and $2.0 \%$, respectively, of their daily feed intake in quebracho tannin.

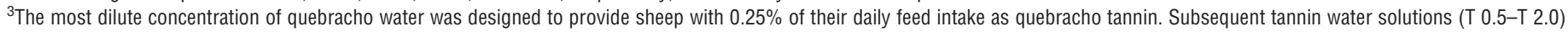
were designed to provide $0.5 \%, 1.0 \%$, and $2.0 \%$, respectively, of their daily feed intake in quebracho tannin.

of the two buckets was reversed daily. For this phase of the trial, the MIXED procedure of SAS (1996) with repeated measures of daily fluid intakes was used to determine if water type, day, and their interaction influenced liquid intakes. Unstructured, compound symmetry, and heterogeneous compound symmetry covariance structures were evaluated and compound symmetry was used (smallest AIC value).

\section{RESULTS AND DISCUSSION}

\section{Cattle Trial 1}

Steers drank less when they were offered tap water than when they were offered tannin water $(P<0.0001$; Table 1$)$. Differences in air temperature and relative humidity during the periods of the trial did not appear to be a major factor in their greater intakes of the tannin-water solutions. Variation in fluid intake among individual steers was generally less during their two times drinking tap water than it was when drinking the tannin-water solutions. The greatest standard deviation (SD) from the mean occurred when the cattle drank the solution with the next-to-highest concentration of quebracho tannin (58\% greater than the SD for the second time they drank tap water). It was almost as high when they drank the solution with the highest level of quebracho tannin $(44 \%$ greater than the SD for the second time they drank tap water). However, none of the steers had low tannin-water intakes that suggested inadequate water intake for good health and productivity (Winchester and Morris 1956). Because they drank considerable amounts of the tannin water solutions, their actual intakes of tannin were slightly higher than expected for each phase of the trial.

\section{Cattle Trial 2}

The interaction between type of water and day was significant $(P<0.0001)$. On the first day of the trial, there was no difference in intakes of tap and tannin water $(P=0.17)$, and similar intakes were also observed on the second day $(P=0.09$; Fig. 1). On the last $10 \mathrm{~d}$, intakes of tap water and tannin water were different $(P \leq 0.002)$ and cattle drank considerably more water on these days, but they also drank some tannin water. Over the first half of the trial, mean daily tannin-water intake ranged from $24 \%$ to $70 \%$ of mean daily water intake, and from $14 \%$ to $38 \%$ of mean daily water intake over the second half of the trial.

\section{Sheep Trial}

Variation in water intake began to increase as soon as CT was added to their water. The SD for liquid intake was $12 \%$ greater for the most dilute tannin water solution than for tap water, and was $228 \%$ and $307 \%$ greater for the next two more concentrated solutions compared to tap water (Table 1). However, for the final and most concentrated tannin water solution offered to the sheep, the SD for intake was only $34 \%$ greater than for tap water intake. Both the lowest and the highest liquid daily intakes by individual sheep were observed when they were offered the solution designed to provide them with $1 \%$ of daily feed intake as tannin. Two of the four sheep had low mean daily intakes of this solution (6.371 and $6.420 \mathrm{~kg} \cdot \mathrm{d}^{-1}$ ) and the other two sheep had high intakes of this solution $\left(10.284\right.$ and $\left.10.720 \mathrm{~kg} \cdot \mathrm{d}^{-1}\right)$. The two sheep with the low intakes may not have been drinking enough water to support good health and productivity. These observations indicate considerable variation in response to the $1 \%$ concentration of tannin, and they are consistent with findings showing 


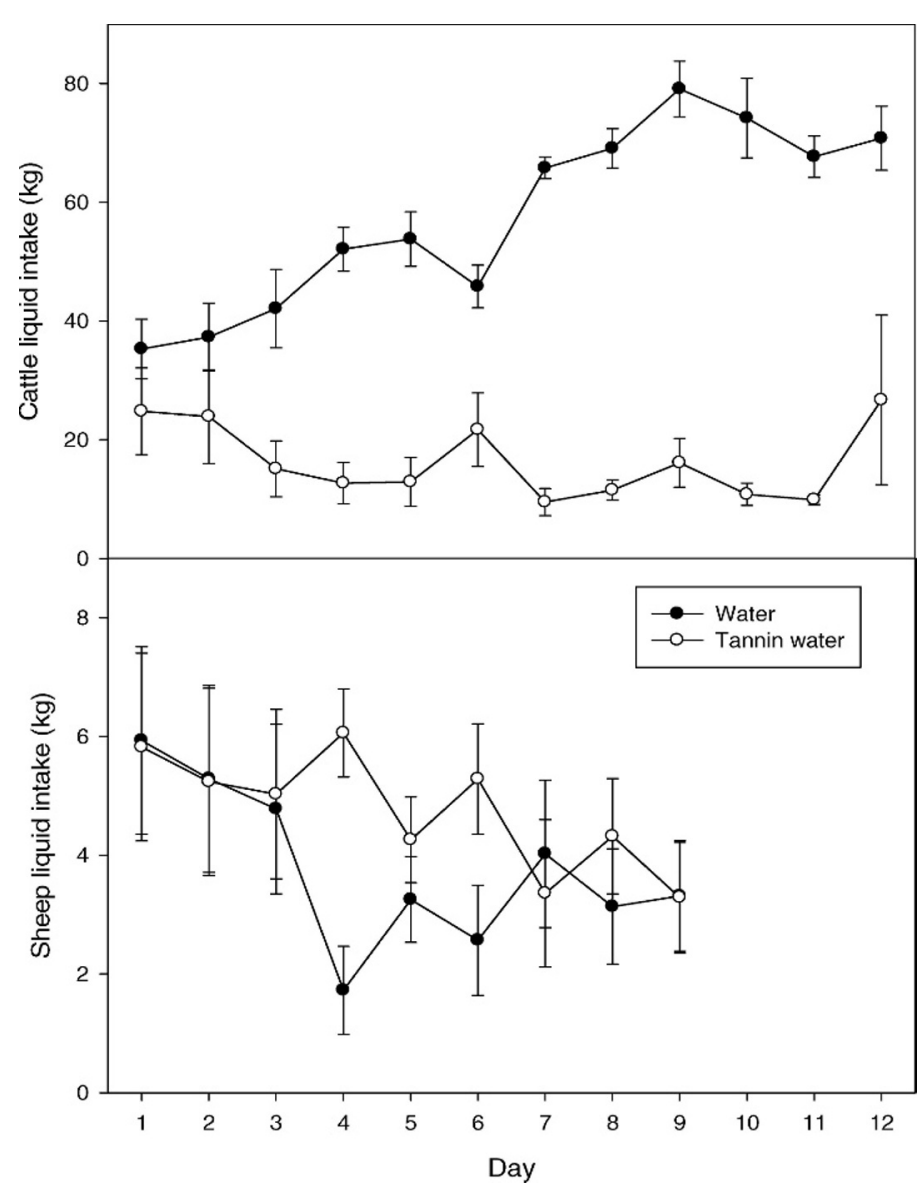

Figure 1. Mean daily intake of tap water and quebracho tannin water for five yearling steers over a 12-d test, and for four wether sheep over a 9-d test. Vertical bars represent the standard error of the means.

that individual ruminants have different tolerances for and intakes of phytotoxins (Pfister et al. 1997; Villalba et al. 2002). Snowder et al. (2001) determined that genetic differences among individual sheep for intake of mountain big sagebrush (Artemesia tridentata Nutt. subsp. vaseyana [Rydb] Beetle) could be used to select sheep with greater tolerance and preference for this toxin-containing shrub.

When sheep were offered a choice between tap water and a tannin-water solution designed to provide $1 \%$ of daily feed intake as CT, as a group they showed no preference for either liquid $(P=0.28$; Fig. 1$)$. Day and the interaction of day and water type were not significant $(P \geq 0.19)$. However, averaging daily intakes of the two liquids for the four sheep masks their daily individual intakes of the two liquids. On any day of the 9$\mathrm{d}$ test there was considerable variation in responses to the two liquids among the four sheep (Fig. 2). Sheep 1 and 3 drank more of the tannin-water solution on 6 of the $9 \mathrm{~d}$, and Sheep 2 drank more of the tannin-water solution on 7 of the $9 \mathrm{~d}$. In contrast, Sheep 4 only drank more of the tannin-water solution on 2 of the $9 \mathrm{~d}$. Variable daily intakes of the two liquids during the 9-d test both within and among sheep is likely a function of individual physiological response to quebracho tannin and their regulation of its intake to minimize detrimental effects of this toxic compound (Pfister et al. 1997) and possibly to derive nutritional benefit from it (Villalba and Provenza 1997). It is

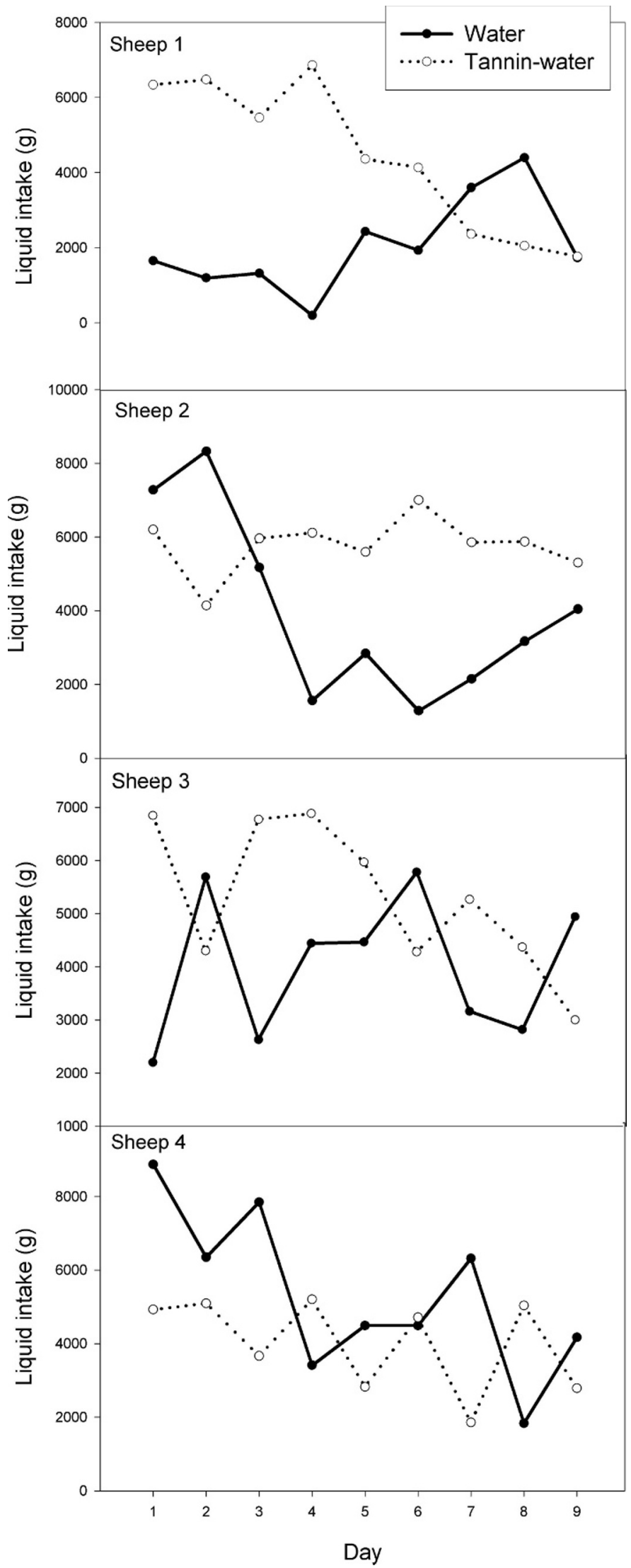

Figure 2. Daily intakes of tap water and quebracho tannin water for four sheep over a 9-d test. 
not clear why the sheep had greater total liquid intake during the first $3 \mathrm{~d}$ of the choice test than they had when they were offered only one of the liquids.

\section{MANAGEMENT IMPLICATIONS}

This study shows that cattle and sheep will ingest CT via their drinking water. Since cattle and sheep often ingest little if any forages containing CT, supplying CT in their water may provide a way to derive benefits associated with its intake if practical and economically viable applications can be developed for this approach.

\section{ACKNOWLEDGMENTS}

Thanks to Curt Klein, Clay Erickson, Charles Flakker, and John Boehm for assistance with this study, and to Michael Ralphs, Eric Scholljegerdes, and Juan Villalba for comments on the manuscript. Thanks to Tannin Corporation for donation of quebracho tannin.

\section{LITERATURE CITED}

Bowman, J. G. P., And B. F. Sowell. 1997. Delivery method and supplement consumption by grazing ruminants: a review. Journal of Animal Science 75:543-550.

Dawson, J. M., P. J. Buttery, D. Jenkins, C. D. Wood, and M. Gill. 1999. Effects of dietary quebracho tannin on nutrient utilization and tissue metabolism in sheep and rats. Journal of the Science of Food and Agriculture 79:1423-1430.

Jefferson, P. G., T. Lawrence, R. B. Irvine, and G. A. Kielly. 1994. Evaluation of sainfoin-alfalfa mixtures for forage production and compatibility at a semiarid location in southern Saskatchewan. Canadian Journal of Plant Science 74:785-791.
Min, B. R., T. N. Barry, G. T. Atwood, and W. C. McNabb. 2003. The effect of condensed tannins on the nutrition and health of ruminants fed fresh temperate forages: a review. Animal Feed Science and Technology 106:3-19.

Pfister, J. A., F. D. Provenza, G. D. Manners, D. R. Gardner, and M. H. Ralphs. 1997. Tall larkspur ingestion: can cattle regulate intake below toxic levels? Journal of Chemical Ecology 23:759-777.

Robbins, C. T., A. E. Hagerman, P. J. Austin, C. McArthur, and T. A. Hanley. 1991. Variation in mammalian physiological responses to condensed tannin and its ecological implications. Journal of Mammalogy 72:480-486.

SAS. 1996. SAS systems for mixed models. Cary, NC, USA: SAS Institute Inc. $633 p$.

Sherlock, R. R., AND K. M. GoH. 1984. Dynamics of ammonia volatization from simulated urine patches and aqueous urea applied to pasture. 1. Field experiments. Fertilizer Research 5:181-195

Snowder, G. D., J. W. Walker, K. Launchbaugh, and L. D. Van Vleck. 2001. Genetic and phenotypic parameters for dietary selection of mountain big sagebrush in Rambouillet sheep. Journal of Animal Science 79:486-492.

Thomas, R. J., K. A. B. Logan, A. D. Ironside, and G. R. Bolton. 1988 Transformations and fate of sheep urine-N applied to an upland U.K. pasture at different times during the growing season. Plant and Soil 107:173-181.

Villalba, J. J., and F. D. Provenza. 1997. Preference for flavored foods by lambs conditioned with intraruminal administration of nitrogen. British Journal of Nutrition 78:545-561.

Villalba, J. J., and F. D. Provenza. 2002. Polyethylene glycol influences selection of foraging location by sheep consuming quebracho tannin. Journal of Animal Science 80:1846-1851.

Vitousek, P. M., J. AbeR, and R. W. Howarth. 1997. Human alteration of the global nitrogen cycle: causes and consequences. Ecological Applications 7:737-750.

Waghorn, G. C., and I. D. Shelton. 1995. Effect of condensed tannin in Lotus pedunculatus on the nutritive value of ryegrass (Lolium perenne) fed to sheep. Journal of Agricultural Science 125:291-297.

Winchester, C. F., AND M. J. MorRIS. 1956. Water intake rates of cattle. Journal of Animal Science 15:722-740.

WolfE, A. H., AND J. A. PAtz. 2002. Reactive nitrogen and human health: acute and long-term implications. Ambio 31:120-125.

Woodward, S. L., G. C. Waghorn, K. R. Lassey, and P. G. Laboyrie. 2002. Feeding sulla (Hedysarum coronarium) reduces methane emissions from dairy cows. Proceedings of the New Zealand Society of Animal Production 62:227-230. 